\title{
Navigating complexities, exploiting shortcuts: Talking about culture as researchers and university educators
}

Daniel Rellstab

\begin{abstract}
Simplistic understandings of culture as 'national culture' and of the relation between language, identity, and culture, have been criticized for quite some time. Today, many teachers in higher education have developed a critical awareness of the complexities of culture and interculturality, and many would no longer subscribe to a simplistic understanding of culture as 'national culture'. Yet despite this awareness, 'national cultural' parlance has not disappeared. Drawing on videotaped interactions among researchers and university educators of German as a Foreign Language during a workshop in West Africa, I demonstrate how we as researchers and university educators navigate complexities when discussing 'culture' and when, how, and why we, then and again, revert to simplistic concepts of culture in our talk. Analyzing the practices and 'common sense resources' we deploy and the discourses we thereby mediate provides insights into how we configure understandings of culture in action and points at problems in the ways we talk.
\end{abstract}

Keywords: culture-in-interaction; expert talk; nexus analysis; stereotypes

Received 14 December 2020; revised version received 1 April 2021; accepted 8 September 2021. Corresponding author: Daniel Rellstab, University of Education Schwäbisch Gmünd, Germany (daniel.rellstab@ph-gmuend.de).

\section{Introduction}

Culture has become a key concept in political discussions, in everyday reasoning, in academia, and in applied language studies and education (see BachmannMedick, 2017; Hormel \& Jording, 2016; Nash, 2001; Plikat, 2016, p. 13). Three decades of discussions of the concept, of its different facets, of its usefulness or inappropriateness, have resulted in the dissipation of its meaning. Some researchers even claim that the impossibility of its definition has become a feature of its use (Bielefeld, 2003, p. 86). Yet the discussions have also resulted in a heightened awareness of the concept's problematic implications. Many researchers and university educators in the field of interculturality no longer subscribe to simplistic 
understandings of culture as 'national culture', and many are cautious especially when writing about culture today (for example, Baumann, 2018; Becker, 2018; Roche \& Venohr, 2018). Despite our awareness, we as researchers and university educators are still susceptible to using simplistic notions of culture- the author of this paper included. Thus, we could rightfully ask if we should still use this concept at all. Some have proposed to keep it and to not 'throw the baby out with the bathwater' (Skiba, 2007). Others have proposed to ban it: 'In my own work I have decided to throw the baby out because it leads to so much confusion and misunderstanding between students, researchers, practitioners, and decisionmakers' (Dervin, 2015, p. 13).

Instead of discussing theoretical arguments in favor of or against the use of 'culture' (see, for example, Dervin, 2015; Hormel \& Jording, 2016), I want to demonstrate how we talk about culture and what could be problematic about it. I aim at a reflection of our practices as researchers and educators (Walsh \& Mann, 2015) based on the analysis of interactions in which I participated. Therefore, my approach can be situated at the threshold of educational action research. As Norton (2019, p. 70-71) points out, the identification of a problem and thinking about ways to tackle it are steps towards change. The questions I address are: How do we as researchers and university educators talk about culture? How do we navigate the complexities of this term? What discourses become visible in our talk, when, and why? Analyzing how we apply the concept of 'culture' in talk, what meaning we attribute to 'culture,' intentionally and sometimes unintentionally, can initiate reflection, make us think about whether we want to keep the concept, and if yes, how we talk about culture and how we teach 'culture' in the classroom. The data used here stem from a two-day workshop for researchers and university educators of German as a Foreign Language (German L2) in West Africa. To analyze my data, I adopt ideas developed in the tradition of mediated discourse analysis and its research strategy, nexus analysis. As an interdisciplinary endeavor that has its roots in anthropological linguistics, interactional sociolinguistics, and critical discourse analysis, it focuses on social actions carried out by material or symbolic means, for example, language, and aims at identifying the discourses which intersect in these social actions (Kuure, Riekki, \& Tumelius, 2018; Scollon \& Wong Scollon, 2004; Wong Scollon \& de Saint-Georges, 2012). At the core of nexus analysis lies the idea that broader social issues are grounded in the micro-actions of social interaction, and that social interaction is a 'nexus through which the largest cycles of social organization and activity circulate' (Scollon \& Wong Scollon, 2004, p. 8). How 'culture', national conceptualizations of culture, stereotypical thinking, racism, and cultural racism are constructed and circulate in higher education has been studied from different perspectives and in different settings for quite some time now (Coloma, 2013; Curtis-Boles, Chupina, \& Okubo, 2020; 
Harper, 2015; Lee, Jon, \& Byun, 2016; Powell, 2000). It has also been addressed in the field of foreign language education and teaching in analyses of, for example, textbooks (Lu, 2012; Marques-Schäfer, Filho, \& Stanke, 2016) or of interviews with foreign language students (see, for example, Koreik \& Fornoff, 2020). Scarcer are analyses of interactions in foreign language higher education settings that focus on the construction of 'cultures' and 'national culture'. From a conversation analysis perspective, Mori (2003) has investigated how Japanese and US-American students display membership of the category 'Japanese' and 'US-American' in initial encounters at a conversation table; Zimmerman (2007) has analyzed how highly advanced Korean learners of Japanese construct culture and interculturality through displaying cultural expertise in discussions about cultural practices; Siegel (2016) has focused on the constructions of 'multicultural identities' of a Korean and a Japanese university student at a US-university. Adapting a critical discourse analysis approach, Cole and Meadows (2013) demonstrate how a language educator in an Indonesian language and literature class avoids naturalizing boundaries between language and cultures. However, how university teachers and educators talk about culture when they are among themselves has not been studied before. Yet scrutinizing how we as teachers and educators talk about culture among ourselves does not only reveal our self-positioning in a specific communicative setting. It allows us to see where and why we fail to live up to our standards and is, therefore, a step towards developing a more critical, self-reflexive attitude that might impact our practices of teaching 'culture,' and thus also 'interculturality.'

\section{'Culture' in German L2 research and education: The case studied}

In German L2 research and education, conceptualizations of culture have drastically changed over the last decades, too, as for example, Kramsch (2009a), Skiba (2007), or Altmayer and Koreik (2010) have shown. Up until the early 1970s, 'culture' was mostly conceptualized in opposition to nature as the sum of everything humans created. Special emphasis was put on the 'big $\mathrm{C}$ culture,' the history, institutions, art, literature, music, the architecture of the respective speech communities (Wolf, 2011). With the advent of communicative approaches and in the wake of the cultural turn in the humanities in the 1970s, the concept became broader. 'Culture' was understood as the system of sense-making, the shared knowledge of speech communities that guides actions and interactions of its members. Theoretical cornerstones of these conceptualizations of culture were, for example, the sociology of knowledge and Alfred Schütz (1953), the interpretative anthropology of Clifford Geertz (1973), or the ideas of collective memory as proposed by Maurice Halbwachs (2006) (see, for example, Altmayer, 2004). 
However, these conceptualizations were still prone to reifications as the focus was mostly on typical, or rather, stereotypical behavior, and the concept of national cultures was still very much alive (see, for example, Kramsch, 2009a).

Even before post-colonial theories became popular in German L2 language teaching and education, the hegemony of the concept of culture as 'national culture' has begun to falter. Already in 1980, the German anthropologist Hermann Bausinger had described cultures as complex formations that are embedded in supra- and transnational networks and dissolve in 'cultural complexity (kulturale Komplexität)' (Bausinger, 1980, p. 61). Yet only in the 21 st century have more complex conceptualizations of culture become widespread. Kramsch, for example, has defined culture by adapting Pierre Bourdieu's notion of habitus and combining it with poststructuralist ideas of deferral and postponement, paradox, and contradiction. Culture, according to her, refers to the sedimented knowledge, the experiences, the feelings, and emotions of a speaking subject and the emerging process of meaning construction in interaction (Kramsch, 2011, p. 355; see also Riedner, 2015, pp. 141-142). Kramsch writes:

[Culture] is seen less as a world of institutions and historical traditions, or even as identifiable communities of practice, than as a mental toolkit of subjective metaphors, affectivities, historical memories, entextualizations and transcontextualizations of experience, with which we make meaning of the world around us and share that meaning with others. (2011, p. 355)

According to Kramsch, culture must be seen 'as a dynamic process, constructed and reconstructed in various ways by individuals engaged in struggles for symbolic meaning and for the control of identities, subjectivities, and interpretations of history' (Kramsch, 2009b, pp. 225-226). Thus, Kramsch moves from the conceptualization of culture as referring to sense-making and practices of identifiable groups to a radical understanding of 'doing culture'. Today it is possible to construct oneself as belonging to a community that is far away or does not even exist anymore. Cultural repertoires as embodied cultural resources are part of 'the biographical memory,' and they are used to shape specific identities. Kramsch's definition is compatible with conceptualizations of culture stemming from critical theory as advanced, for example, by Hormel and Jording (2016). Building on the work of Stuart Hall and the German education scientist Paul Mecheril, Hormel and Jording underline that 'doing culture' is a categorization process in which differences are constructed and power is negotiated. According to them, 'culture' is an ideological structure that is mobilized to legitimize processes of exclusion and that becomes productive when inequalities are re-created (Hormel \& Jording, 2016, p. 222). 
The concept of 'culture' is still very important in German L2 research and education today, yet different conceptions of culture co-exist in the field. Some are still rather static, 'modernist', or, to use Adrian Holliday's (2011) concept, 'neoessentialist;' culture is defined as the value system of a group or even a nation. Such conceptualizations can often be found in textbooks and pre-university German L2 classrooms (Plikat, 2016, p. 15; Rellstab, 2021). They still retain elements of cultural chauvinism because they often differentiate between 'good,' Western, liberal cultures and 'problematic,' non-Western, illiberal ones (Holliday, 2011, pp. 6-10). However, most researchers and university educators have become aware that simplistic concepts of culture are problematic as they project a simplistic, stereotypical, often ethnocentric and sometimes even racist view of the world. At least in academic texts, complex concepts of 'culture' and an understanding of cultures as co-constructed and dynamic are advocated (for example, Baumann, 2018; Becker, 2018; Kramsch, 2009a; Roche \& Venohr, 2018). Yet despite the wide dissemination of more 'cosmopolitan' and 'critical cosmopolitan' approaches (Holliday, 2011, pp. 12-13), simplistic understandings of culture have not disappeared from research and university education. However, if we perpetuate these understandings in our writings, in our talk, and in the classroom, we as educators do not only assist in sustaining a world view that is stereotypical and highly problematic. We also fail to educate our students to become critical thinkers. Hence, we should strive to free ourselves from simplistic notions of culture. Yet as the following analysis demonstrates, this is far from simple. As the interactions from the workshop I will discuss suggest, the adoption of one of the two opposing points of view is rather a local, interactional achievement than fixed once and for all.

\section{Discourse analysis as a starting point for reflexive practice}

Reflexive practices have enjoyed wide acceptance in language teaching and education for quite some time and have been institutionalized at different levels to varying degrees of success. As Hale, Nanni, and Hooper (2018) and Ghafarpour (2017) have shown, close analyses of the way we talk and interact offer us detailed insights into our practices as teachers and educators and thus can initiate reflection and, if necessary, change. Here, reflection was initiated by the analysis of data that stem from a two-day workshop for German L2 researchers and university educators in West Africa. The topic of the workshop was 'Approaches to Researching Interculturality.' Ten researchers and university educators participated; they held passports from different West African and Western European countries, and most of them held a PhD. Some of them had known each other for a long time, others 
met for the first time. I was one of the organizers of the workshop and participated too. Some of the participants were German L1 speakers, as I am, some were German L2 speakers. The language skills of the latter were excellent, most of them had lived for extended periods in German-speaking countries, and linguistic phenomena typical of L2 interactions, for example, word searches or non-grammatical syntactic constructions (see, for example, Kurhila, 2006), could rarely be found in the data. The workshop sessions were video- and audiotaped and transcribed according to GAT 2, a transcription convention that has been developed by German researchers and is widely used in German interaction research (Selting et al., 2009).

To make sense of the workshop data, I adopt an analytical strategy that has been developed in mediated discourse analysis, so-called nexus analysis (Wong Scollon \& de Saint-Georges, 2012). Nexus analysis is a highly flexible mode of inquiry; it assumes that social discourses circulate through all moments of human action. By focusing on social actions, nexus analysis reveals how discourses mediate social actions (Scollon \& Wong Scollon, 2004). These discourses become visible when the analyst takes the three 'essential material entities constitutive of any mediated action' into account: the historical bodies of the people involved, the interaction order, and the discourses in place (Wong Scollon \& de Saint-Georges, 2012, p. 71). The historical body refers to the embodied life experiences that are constitutive of the way we act. It is related to Bourdieu's concept of 'habitus' as a mostly unconscious 'generating principle of social forms of practice' (Schwingel, 2000, p. 63). The idea of the interaction order is taken from Erving Goffman. According to Goffman, the interaction order refers to the social and interactional norms which influence the ongoing interaction, yet are, at the same time, reconstructed in and through the interaction (Goffman, 1983). It encompasses also specific communicative genres (Knoblauch, 2005), or specific communicative projects (Linell, 1998). Discourses in place refer to the material, conceptual, and ideological phenomena in place at the moment of action (Hult, 2019, p. 140). Thus, according to nexus analysis, 'social actions are nexus points for the interplay of structure and agency' (Hult, 2019, p. 141). Nexus analysis is ideally conducted in three steps: first, when engaging the nexus of practice, important social actions, the actors, and the discourses and concepts that are relevant in the moment are identified. Second, the nexus of practice is navigated. This involves the collection of data and the analysis of the selected data. As nexus analysis focuses on social issues, its goal is not merely analytical: as a third step, it aims at change (Lane, 2014). Although nexus analysis is often applied in long-term ethnographic projects, it is possible to utilize concepts and methods of nexus analysis to examine a smaller event or actions too (see Aarnikoivu, 2020).

In the following, I will zoom in on fragments of the workshop where the participants discuss the concept of culture to find a definition all can agree on, and 
on fragments where the participants tell stories and make jokes and thereby engage different concepts of culture too. In doing this, I navigate a nexus of practice within a community I myself belong to.

\section{Culture in interaction}

We do not act consistently in everyday life (Wacquant, 2016), and we apply concepts in inconsistent manners in everyday talk and reasoning (see, for example, already Schütz, 1944). In an academic context, however, we strive for consistency, or at least, we should. Yet stark inconsistencies can appear in academic discussions, also when we talk about 'culture'. Sometimes we seem to be very careful to navigate the complexities of the concept of culture. At other times, we use shortcuts and fall back into simplistic talk about culture that undercuts our aims to be precise.

Tiptoeing around definitions, promoting solutions

At the beginning of the workshop, after the round of self-presentations, I initiate a debate on the meaning of 'culture' that lasts for approximately one hour. The first part of the debate revolves around the distinction between nature and culture. As the following fragment demonstrates, Robert (RT) deconstructs this distinction already in his opening argument. The fragment sets in after my (DR) suggestion to discuss the notion of culture and before I invite the participants to co-develop a common understanding of the concept:

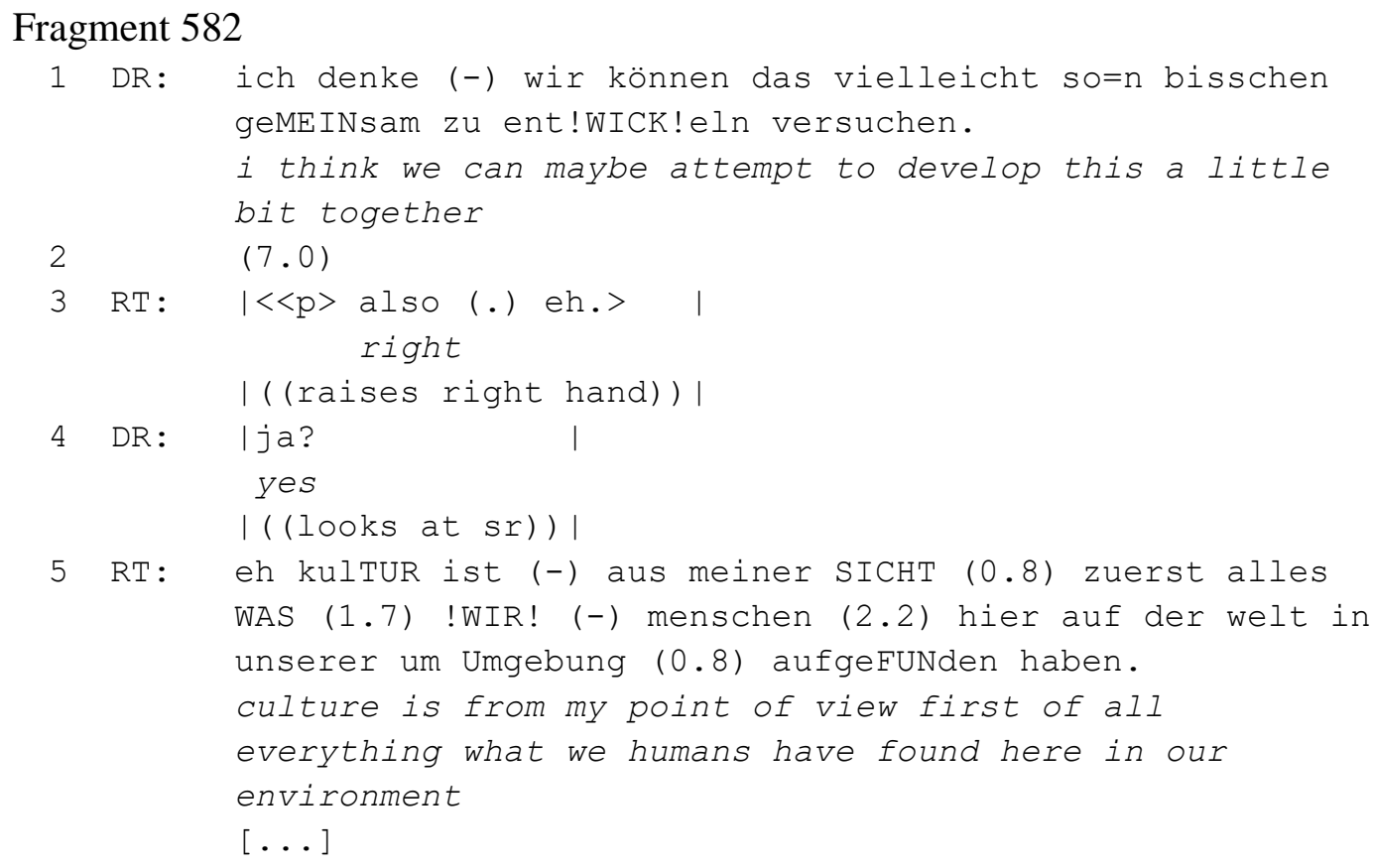




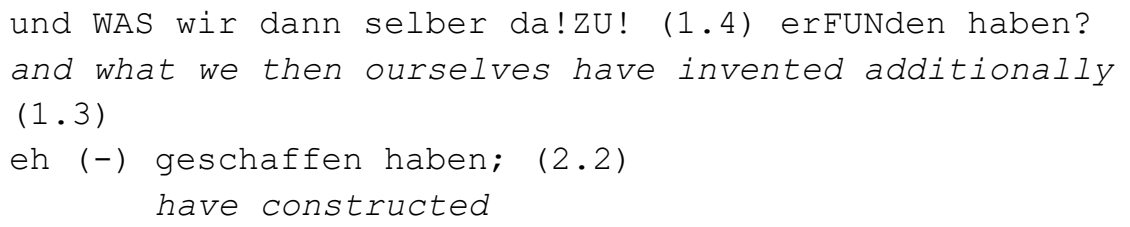

My invitation bears traces of uncertainty: the epistemic marker I think (1) and the phrase maybe a little bit (1) soften the imposition of suggesting to pursue the communicative project of developing a common understanding of 'culture'. All the participants are addressed as equals; no one is singled out as epistemic authority. A very long gap of seven seconds follows; this indicates that finding a solution will not be easy. Robert self-selects as the next speaker with an inference indicating right (3), thereby projecting the provision of a definition. After he is licensed as the next speaker, he begins a formulation: culture is. Before he proceeds, he pauses, indicating hesitancy, and then inserts the epistemic marker from my point of view (5), thereby downgrading the certainty and the generality of the projected definition. The definition itself contains several pauses: two long pauses frame the subject of the first relative clause, we humans (5), underlining the focus of the definition; one longer pause is placed before the nonfinite verb invented (6), and a longer pause before the increment have constructed (7). The pauses structure Robert's argumentation and emphasize the important elements of his definition. At the same time, they contribute to the tentative character of his definition. Summarizing his explanations after having listed elements belonging to culture in a part that is omitted here, he claims:

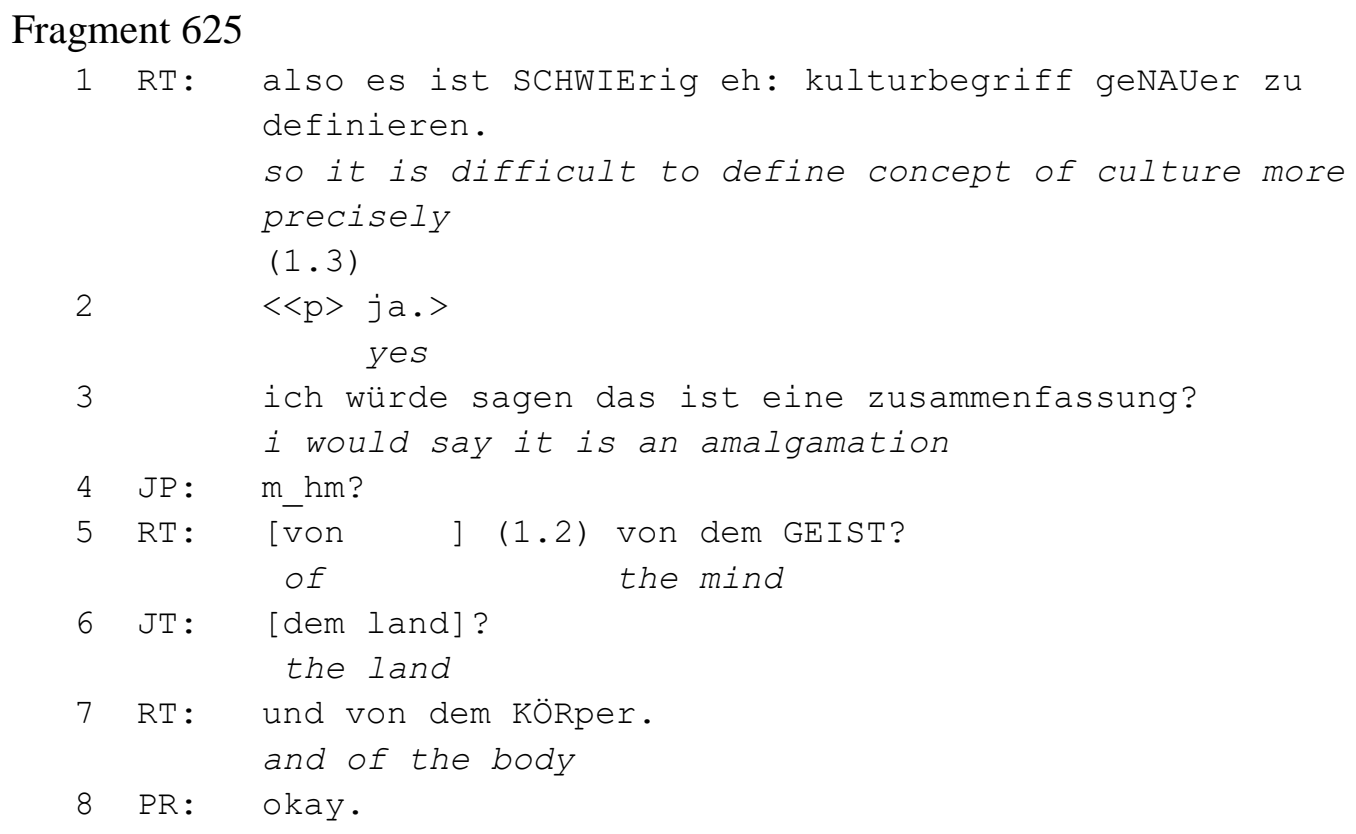


Before Robert provides a summary of his understanding of culture, he pre-empts criticism by referring to general difficulties when defining culture: so it is difficult (1). As in the previous fragment, he epistemically downgrades his projected definition with the marker $i$ would say (3), thereby framing his definition as tentative and waving epistemic authority. Then he provides a more anthropocentric version of his previous definition of culture as an amalgamation (3), understood in the sense of an amalgamation of body and mind.

Robert's contribution initiates further discussion of the relation between nature and culture. His definition is contested by Caroline (CT), who claims:

Fragment 641

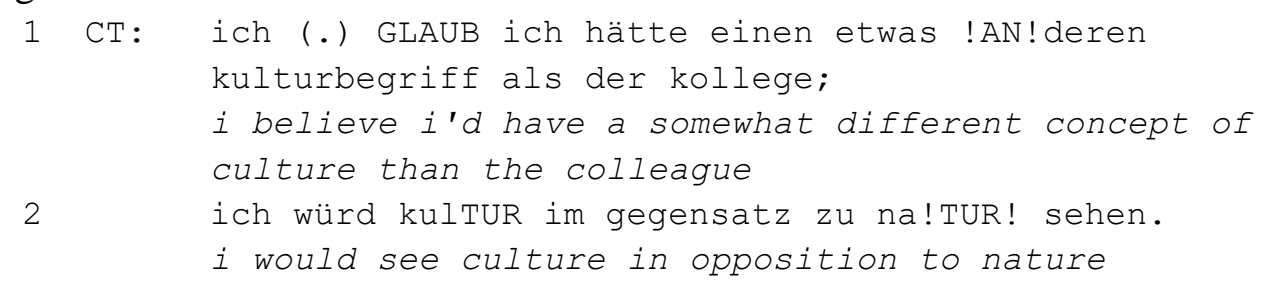

Caroline does not align with Robert; she promotes a more traditional understanding of the distinction between nature and culture. Yet similar to Robert, she downgrades epistemic certainty by using the markers $i$ believe and $i$ would see, thereby mitigating any claim to epistemic authority; neither does she attempt to topple the definition provided by Robert.

The participants do not reach a final verdict, and Christian (CF) finally provides an interim assessment. He states:

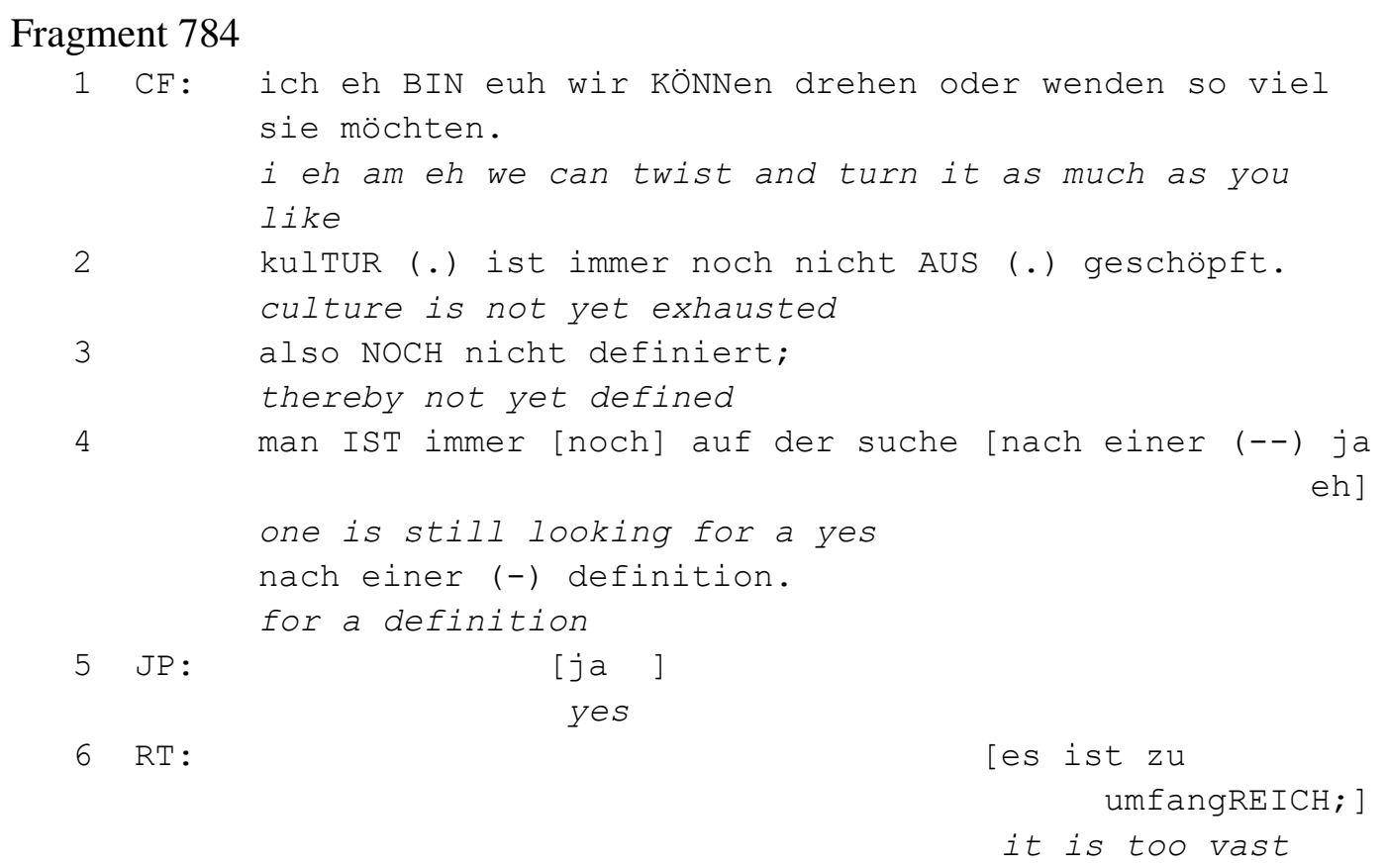


Here, a notable change in claiming epistemic authority can be observed. This is related to the change of the interaction order. Christian does not attempt to define culture. He provides an assessment of the previous discussion. Christian begins his turn with a collocation indicating a final verdict. In it, he self-repairs and thereby upgrades the validity of his claim: I eh am to we can (1). He then presents his assessment as a generalized fact: it is impossible to present a standard definition of culture. Jean-Paul (JP) (5) and Robert (6) agree.

This assessment does not terminate the discussion. From an interactional perspective, abandoning the task of developing a shared understanding of 'culture' would amount to abandoning the communicative project that I set into motion in the beginning. Thus, the debate continues. Finally, the participants of the workshop find solutions. The definitions they advance can be categorized as post-modernist, cosmopolitan, and in line with current theoretical thinking in the field. Unlike before, these definitions are formulated with epistemic certainty and authority:

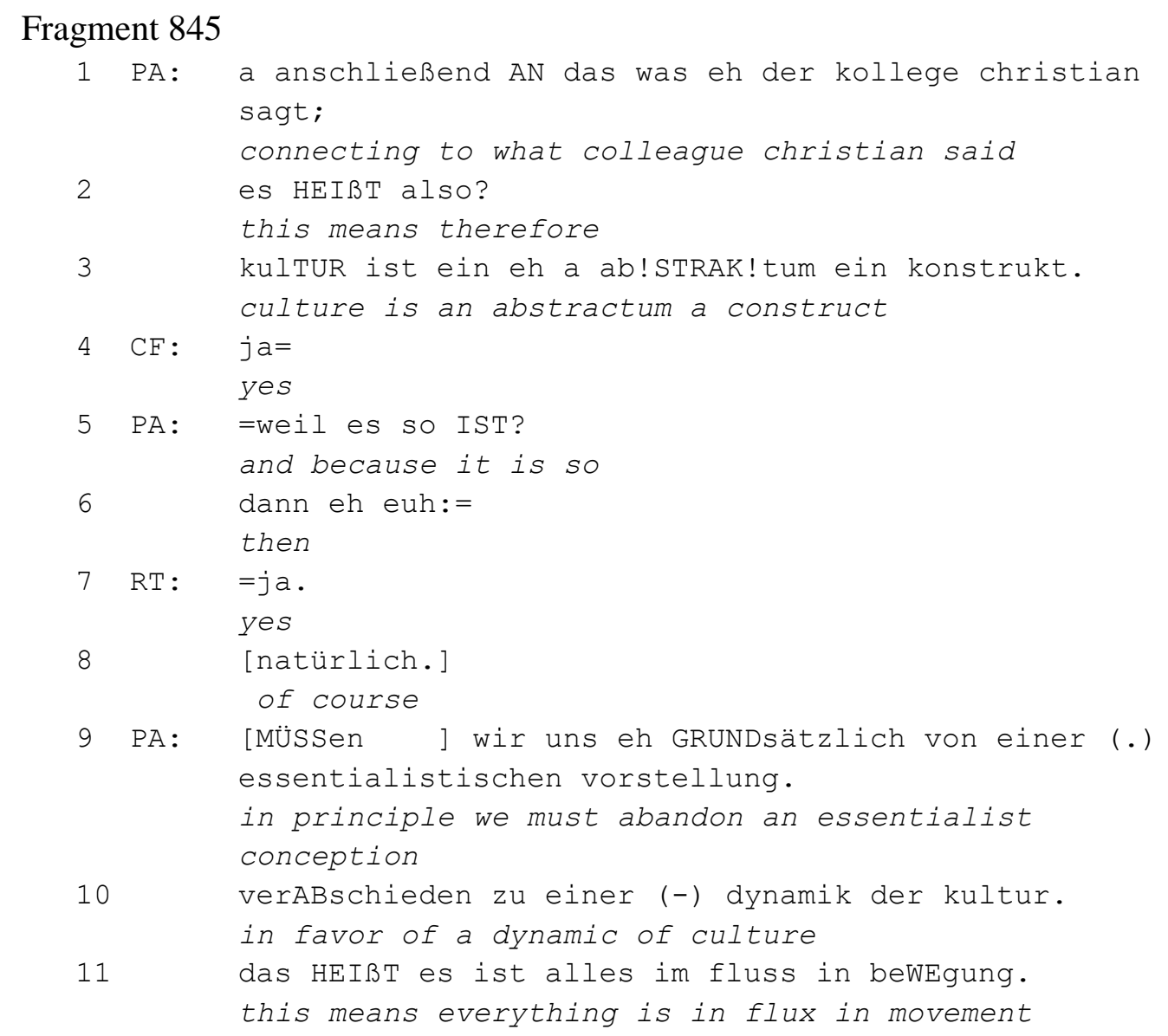

Unlike the previous speakers, Philippe (PA) displays epistemic certainty and authority and infers epistemic responsibility from this authority. Linking his turn to the claim of his colleague Christian-connecting to what colleague christian said 
(1), he concludes this means therefore (2) that culture is a construct (3); this conclusion is supported by Christian (4) and Robert (7). Based on this conclusion, Philippe formulates a deontic claim ${ }^{1}$ : in principle we must abandon an essentialist conception in favor of a dynamic of culture $(9,10)$. Providing access to the source of his knowledge and demonstrating how he reasons, he increases epistemic certainty and props up his epistemic authority. He suggests that we should think about culture in dynamic terms.

Katharina (KD) aligns with him when she criticizes national or topological conceptions of culture:

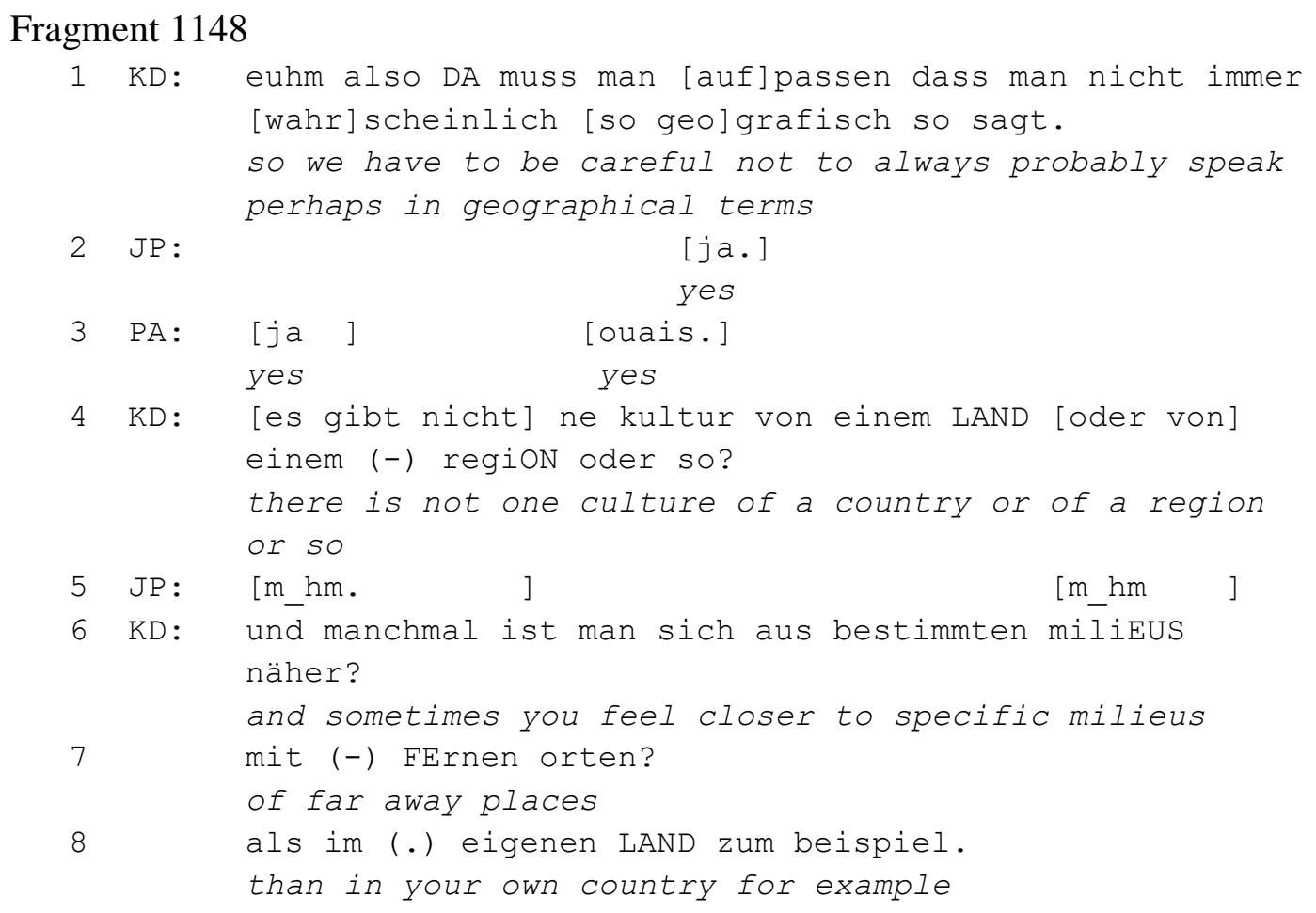

She makes a deontic claim-we have to be careful (1) - not to use culture in a topological sense and supports her claim with an example: one can feel close to people regardless of their whereabouts (6-8). Philippe (3) and Jean-Paul (5) indicate consent. It seems as if the group has reached a common understanding at this point: 'Culture' is complex and dynamic, and it should not be defined in topological or national terms. Those who advance it demonstrate their knowledge of the ongoing theoretical discussions in the field and speak as experts; others signal consent. However, this understanding is a local and contingent achievement and abandoned within minutes in favor of a much more traditional understanding of culture that seems deeply embedded in our historical bodies.

\footnotetext{
${ }^{1}$ Deontic: Expressing duty or obligation.
} 


\section{Telling stories, making jokes}

The caution and the restrictions imposed on using simplistic notions of culture disappear as soon as the interaction order changes and the participants, the author of this paper included, are engaged in different communicative projects. The following two fragments stem from a discussion of Edward Hall's contribution to the field of intercultural communication research. Hall's work is placed in its historical context, the importance of his work is valued yet also criticized as advancing stereotypical thinking. However, as the following fragments demonstrate, stereotypical thinking is also visible among participants of the discussion.

In the first fragment, I am standing in front of the classroom, talking about Hall's claim that space is differently organized in different cultures. I illustrate his claim by drawing on an existing stereotype on the behavior of people in Finland and my own experiences as a person who lived in Finland and traveled back and forth between Finland and Switzerland for quite some time; I illustrate my point by enacting a 'small story' (Bamberg \& Georgakopoulou, 2008):

Fragment 1326

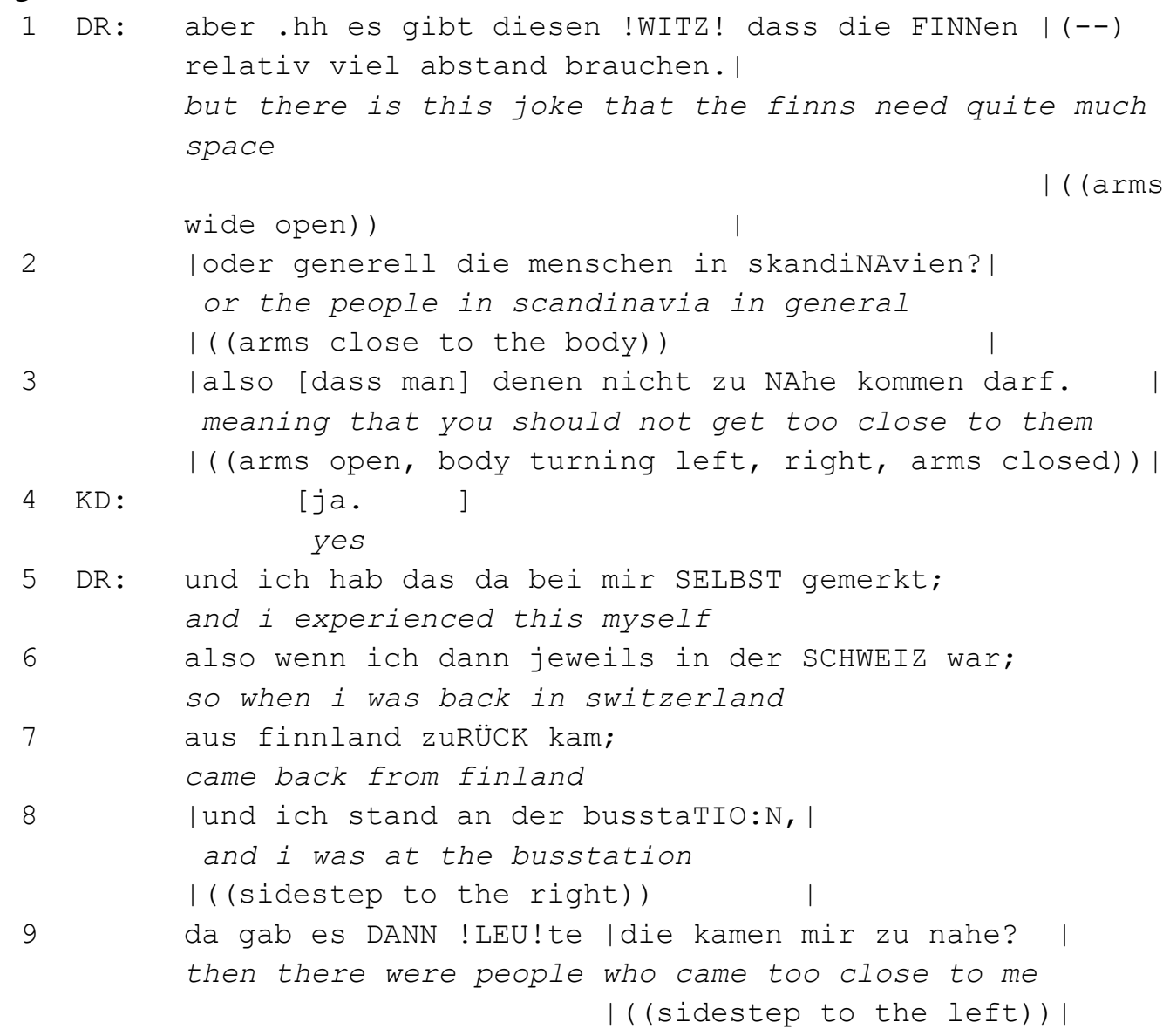




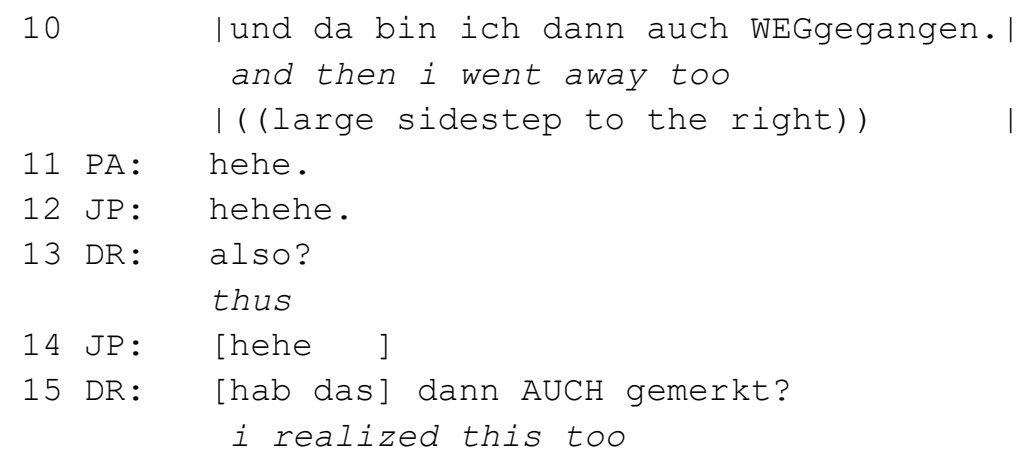

My illustration consists of two parts. The first part refers to this joke that finns need quite much space (1), which is corrected to the people in scandinavia in general (2), and then explained as that you should not get too close to them (3). To illustrate Hall's theory on the cultural variance of the organization of space, I make a national and geographical stereotype relevant and thereby construct a category consisting of Finns and Scandinavians and their typical behavior. The stereotype and the category are carefully placed within the scope of 'this joke,' thus do not undermine Katharina's insistence that country-specific or region-specific cultures do not exist. However, in what follows, the stereotype is reified and reasserted. What I called 'a joke' is transformed into an assertion in an embodied multi-unit narrative. I organize the transition from the joke to the narrative through a story preface: and $i$ experienced this myself (5). Then I set the scene in the background segment (Goodwin, 2016, p. 199): the country and the specific location of the story are explicated (6-8). The performance of the story begins in line eight when I sidestep to the right, embodying the arrival at the bus stop. The climax of the story is reached when I relate what happened there: then there were people who came too close to me and then $i$ went away too $(9,10)$. Both the approach of the people and my stepping away are performed in front of the others. There is contrast built into my performance: the step to the left which indicates the people approaching me at the bus station, is short (9). The step to the right, which is done while talking about distancing, is twice as large (10). Through this exaggerated step to the side, I position myself away from the Swiss and invite the others to laugh at me, or the situation. I succeed: both Philippe and Jean-Paul treat my turn as funny $(11,12)$, and Jean-Paul continues to laugh while I summarize my experiences $(14,15)$. The successfully performed story reconstructs a national or at least topological understanding of culture by generalizing over the behavior of people living in Finland or Scandinavia and Switzerland (see, for example, Sajavaara \& Lehtonen, 2011). Moreover, in and through my self-categorization, I present myself as having acquired character traits typically attributed to Finns because of my prolonged living in Finland. This self-categorization rests on the assumption that people assimilate when they live in a different country and become like locals. Thus, my 
embodied narrative re-enacts simplified views on culture and acculturation to land a joke.

A bit later, stereotypes are made relevant after I compared Hall's theory to Brown and Levinson's (1987) theory on negative politeness, broach the issue of talking to foreigners in public transportation, and ask how people would behave 'here' - a question which is loaded too. Katharina answers my question by relating a story:

\section{Fragment 1387}

$1 \mathrm{KD}$ : auf dem !FLUG! nach (city in West Africa)?

on the plane to (city in West Africa)

2 wenn man das flugzeug NIMMT?

if you take the plane

3 da fängt (-) ganze HALbe flug immer miteinander an zu quatschen.

always half the whole plane begins to chat with each other

4 SOFORT ist irgendwie; $=$

immediately there is somehow

5 JP: $=s$ he he.

6 RT: völlig norMAL.

totally normal

7 PA: ha (.) ha

$8 \mathrm{CF}: \quad[(\mathrm{xxx})$

9 KD: [ich saß NEUlich] <<laughing> zwischen> [von] äthiopien hierher?

$10 \mathrm{JP}$ :

recently I was sitting between from ethiopia to here

11 PA: m_hm?

$12 \mathrm{KD}$ : zwischen $(-)$ den LEUten?

between the people

13 und ich hatte das geFÜHL?

and $i$ was under the impression

14 sie haben es war eine !RIE!sige gruppe die zuSAMMen gereist ist?

they have it was a huge group that was traveling

together

aber eigentlich haben sie ALLe: irgendwie bei der war beim

but actually they all met somehow at while

warten (.) angefangen miteinander zu REden.

waiting they started to talk with each other

16 und dann ging=s (.) | IMMer über meinen kopf [hinweg.] |

and then it always went over my head

I ((moves arms above her head)) | 


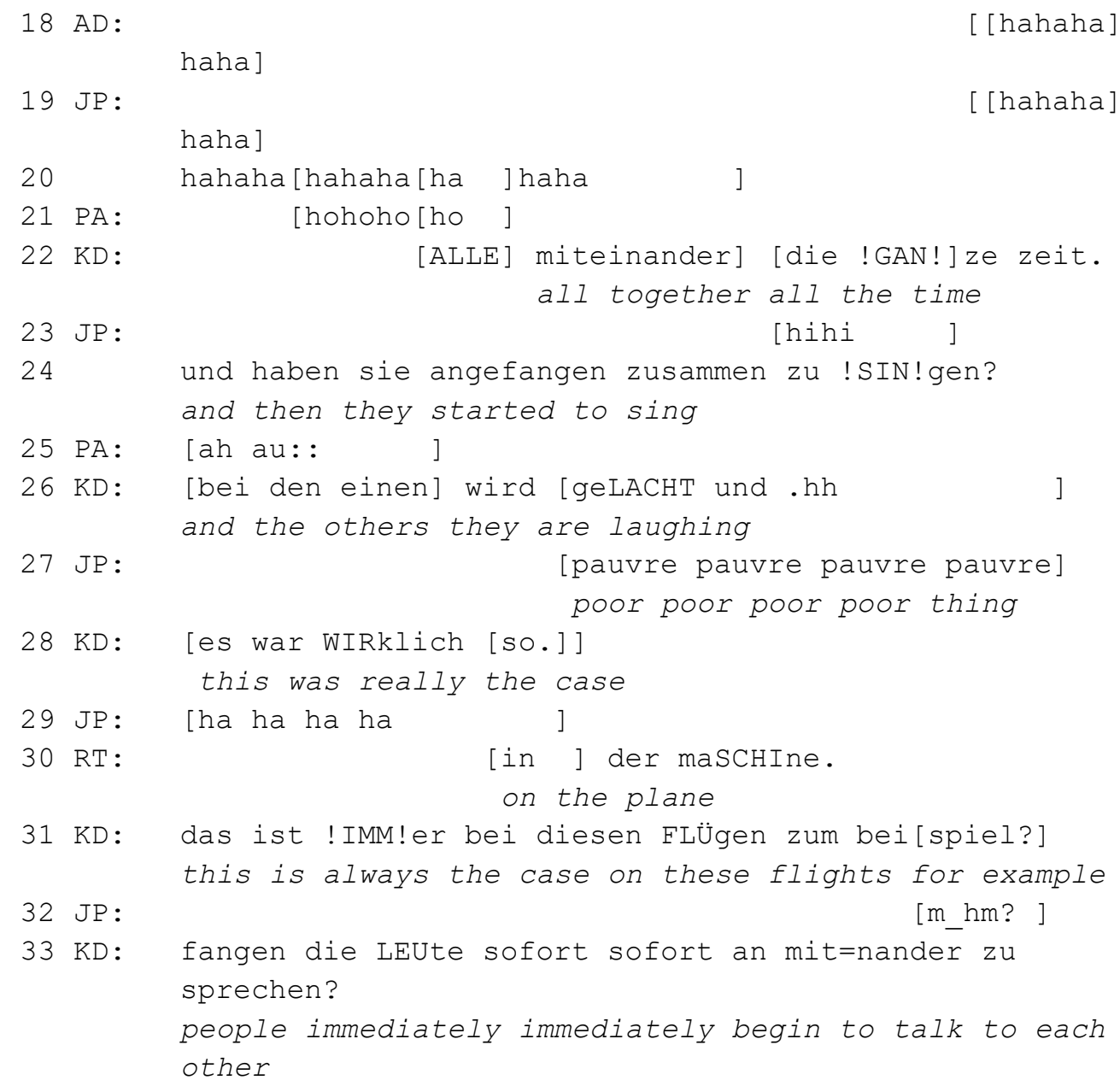

Katharina refers to behavior on flights on the African continent where, according to her, people immediately begin to chat with each other (3). John and Philippe, who are looking at Katharina, orient to the slight exaggeration and treat her turn as a laughable (5, 7; see Glenn, 2003). Robert agrees with Katharina, yet assesses her observation as rather irrelevant: totally normal (6). Katharina then tells what happened to her lately: she sat on a plane between people who had recently met and who talked in a very animated way with each other. Through laughter in the background segment (9), she marks the projected story as funny. The climax of the narrative is embodied and illustrated by hand movements over her head: and then it always went over my head (16). Katharina, as I did, exaggerates, which invites the audience to perceive the story as funny, again. She succeeds. This first part of the climax is followed by a burst of shared laughter that displays strong affiliation and alignment in the group (17-21). While people are still laughing, Katharina expands the story and renders it more dramatic, first by explicating always to all together all the time (22) and then by relating how the tumult increased: people began to sing and laugh $(24,26)$. At this point, the assessment of Katharina's narrative changes. While the first part of the segment was treated as funny, the 
second part is assessed as requiring sympathy: Philippe introduces a response cry (25; Goffman, 1981), Jean-Paul categorizes her in French as poor thing (27). Katharina enters the coda of her story in overlap with John who is still laughing, and asserts the generality of her experience, again $(31,33)$. The stance Katharina takes towards the experience is not negative, yet rather one of bewilderment or amusement. Yet her colleagues take a negative stance towards the behavior of 'these people' and demonstrate sympathy. In this multi-unit turn, the group constructs the category of people on continental planes in Africa who get acquainted very quickly and interact animatedly. In the beginning, Katharina does not explicitly exclude herself from this category (3). Yet in the course of the story, she introduces a division between the passengers and herself. There are 'these people' who instantly begin to talk to each other, who sing and make jokes, and there is the narrator who sits between them and is bewildered.

After a lengthy comment that is excluded here, the group reifies the category and specifies it by making use of stereotypes. Katharina introduces a difference between passengers on intra-continental planes in Europe and passengers on intercontinental planes to Africa:

Fragment 1438

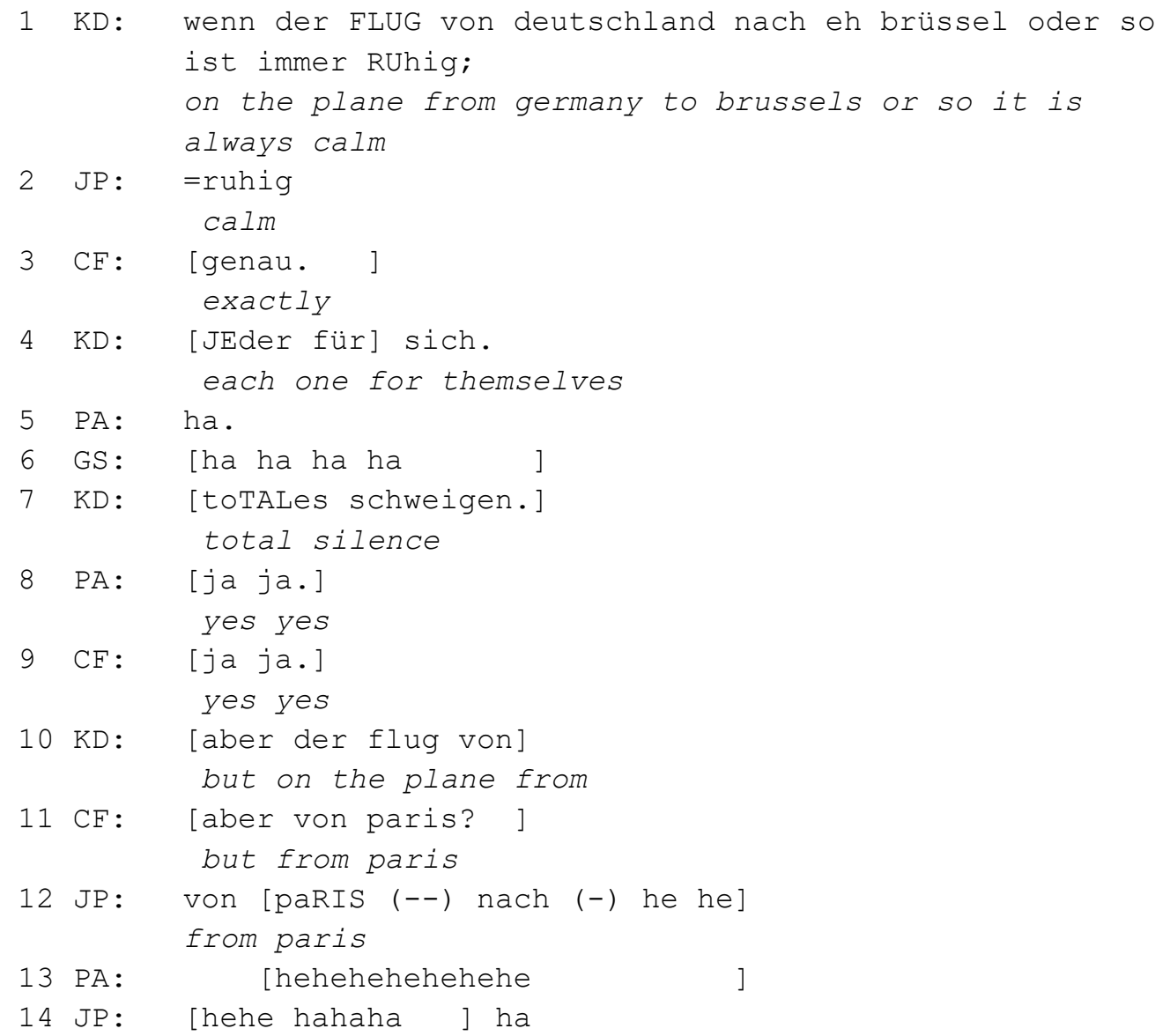




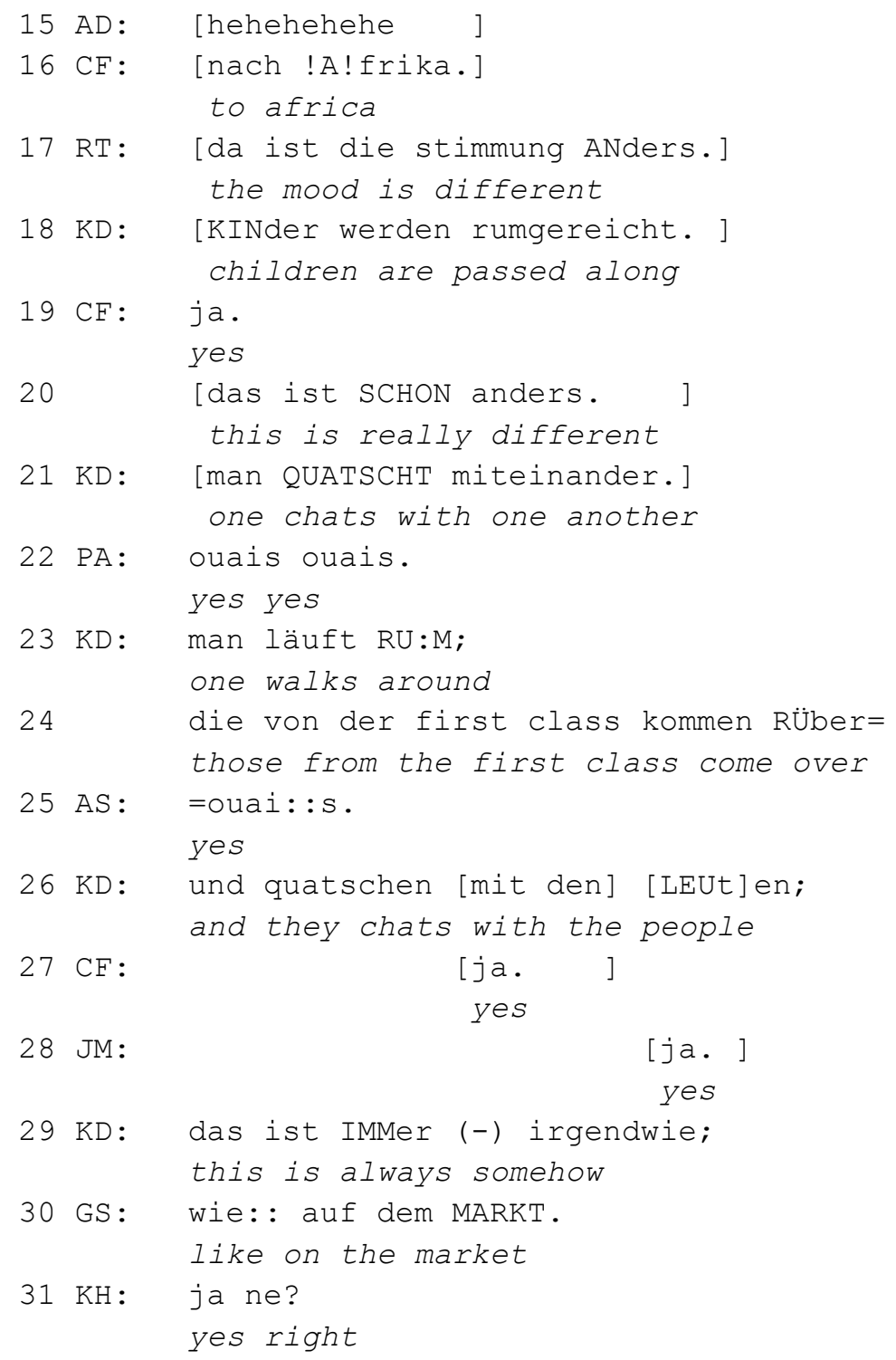

Katharina claims that everything is quiet on intra-European flights: each one for themselves (4), total silence (7). She thereby invokes the image of passengers that are silent, quiet, by themselves, and maybe also a bit boring. The colleagues constantly confirm what she says through repetition (2), confirmation $(3,8,9)$, and laughter $(5,6)$. In lines 10 and 11, both Katharina and Christophe project a contrast to this situation in their but-prefaced turns in overlap: but on the plane from (10); but from paris (11). The single mentioning of Paris initiates laughter (12-15). While others laugh, Christophe specifies the destinations of flights from Paris and thereby also its passengers: these are planes to Africa with, assumedly, passengers from Africa (16). Partly in overlap, Katharina details what is different on planes to Africa: children are passed around, people talk to each other, first-class passengers walk to the economy class to chat $(18,21,23,24,26)$. Others agree $(22,25,27,28)$. 
Gabriel (GS) compares the situation on inter-continental planes to Africa to a market (30), which is corroborated by Katharina (31). Collaboratively the workshop participants re-construct traditional stereotypes of people from Europe and people from Africa. These re-constructions are self- and other-categorizations as some of the people in the workshop identify as 'coming from' Africa, others as 'coming from' Europe. The claim that culture should not be defined in a topological sense is, at this point, forgotten.

\section{Conclusions}

As researchers working on interculturality and as university educators teaching interculturality, we are aware that 'culture' is a complex concept and should not be understood in a national or topological sense. Yet the fragments of the workshop demonstrate how inconsistently we sometimes talk about culture. The analyses suggest that as long as we theorize about the meaning of the concept of 'culture,' we are careful to avoid simplistic conceptualizations, we hedge, we downgrade our certainties, and we advance complex understandings. Yet when we tell stories and intend to land a joke, we loosen our standards and fall back into simplified versions of 'the cultural.' This happens within seconds and minutes of our interactions. From an interactional perspective, this is not astonishing: telling stories follows a different interaction order than discussing complex definitions. During expert discussions, we are guided by our habitus as researchers and cultural experts. When discussing definitions, we construct ourselves as experts in the field, we demonstrate that we are aware of the many difficult implications the notion bears, and we anticipate criticism by emphasizing our uncertainty and by downgrading our epistemic authority. Yet when we tell a story, we want to catch the audience's attention, we exaggerate, we invoke stereotypes, and we introduce salient contrasts to make our stories graspable and funny. Stereotypes on what we call 'cultural differences' are pervasive, they can be easily exploited, and they come in handy. Yet when using such categories and stereotypes, we reconstruct simplistic views of the world and undermine our attempts at finding a definition of 'culture' that is adequate, fair, and non-essentialist. Thereby, we play into the hands of powerful ideologies that structure the world according to national, ethnic, and 'racial' lines without probably wanting it, and unwillingly help to reconstruct power inequalities. These are, of course, qualitative analyses of fragments of one specific workshop. Yet they demonstrate that even researchers and university educators who strive to adhere to post-modern, critical cosmopolitan views of culture fail, time and again, fall back into simplistic ways of talking, and have not freed themselves from more essentialist understandings of culture. This is not surprising. Our historical bodies 
have been influenced by powerful discourses that we cannot simply shake off, and we as human beings will never be capable of acting and speaking constantly consistently. Yet we need to become aware of social actions that are at odds with our theoretical beliefs, positions, and convictions. If we as researchers and university educators intend to keep the concept of 'culture', yet intend to advance non-essentialist notions of 'the cultural,' we need to know how we talk about culture in lively debates with peers, in the classroom with students, yet also outside of academia. Otherwise, we will perpetuate simplistic and problematic understandings of culture. When we have become aware of our failures, we can think about how to change and begin to revise our practices as university teachers and educators in a fundamental and not only superficial way. 
Journal of Praxis in Higher Education, Special Issue, Vol. 3, No. 2 (2021)

\section{Author biography}

Daniel Rellstab is Professor of Intercultural German Studies and Multilingualism at the University of Education, Schwäbisch Gmünd, Germany, where he teaches applied linguistics, multilingualism, and interculturality. He earned his $\mathrm{PhD}$ and his venia legendi (Habilitation) from the University of Bern, Switzerland. Previously, he worked at the University of Bern, Switzerland, the University of Vaasa, Finland, and the University of Jyväskylä, Finland. His research centers on discourse and interaction in super-diverse and multilingual settings, semiotics, and language learning. 


\section{References}

Aarnikoivu, M. (2020). Studying international doctoral researchers: Nexus analysis as a mode of inquiry. Journal of Praxis in Higher Education, 2(2). https://doi.org/10.47989/kpdc82

Altmayer, C. (2004). Kultur als Hypertext. Zu Theorie und Praxis der

Kulturwissenschaft im Fach Deutsch als Fremdsprache. München: Iudicium.

Altmayer, C., \& Koreik, U. (2010). Geschichte und Konzepte einer

Kulturwissenschaft im Fach Deutsch als Fremdsprache. In H.-J. Krumm, C. Fandrych, B. Hufeisen, \& C. Riemer (Eds.), Deutsch als Fremd- und Zweitsprache. Ein internationales Handbuch. (pp. 1378-1391). Berlin: Mouton de Gruyter.

Bachmann-Medick, D. (2017). Cultural turns: A matter of management. In W.

Küpers, S. Sonnenburg, \& M. Zierold (Eds.), Rethinking management. Perspectives and impacts of cultural turns and beyond (pp. 31-55). Wiesbaden: Springer. https://doi.org/10.1007/978-3-658-16983-1_2

Bamberg, M., \& Georgakopoulou, A. (2008). Small stories as a new perspective in narrative and identity analysis. Text and Talk, 28(3), 377-396. https://doi.org/10.1515/TEXT.2008.018

Baumann, B. (2018). Sprach- und kulturreflexives Lernen in Deutsch als Fremdsprache. Berlin: Frank \& Timme.

Bausinger, H. (1980). Zur Problematik des Kulturbegriffs. In A. Wierlacher (Ed.), Fremdsprache Deutsch. Grundlagen und Verfahren der Germanistik als Fremdsprachenphilologie I (pp. 57-69). München: Fink.

Becker, C. (2018). Kulturbezogenes Lernen in asynchroner computervermittelter Kommunikation. Eine empirische Untersuchung von Online-Diskussionen im universitären Landeskundeunterricht. Tübingen: Narr Francke Attempto.

Bielefeld, U. (2003). Nation und Gesellschaft. Selbstthematisierungen in Deutschland und Frankreich. Hamburg: Hamburger Edition.

Brown, P., \& Levinson, S. C. (1987). Politeness. Some universals in language usage. Cambridge: Cambridge University Press.

Cole, D., \& Meadows, B. (2013). Avoiding the essentialist trap in intercultural education; Using critical discourse analysis to read nationalist ideologies in the language classroom. In A. J. Liddicoat \& F. Dervin (Eds.), Linguistics for intercultural education (pp. 29-47). Amsterdam: John Benjamins.

Coloma, R. S. (2013). 'Too Asian?' On racism, paradox and ethno-nationalism. Discourse: Studies in the Cultural Politics of Education, 34(4), 579-598. https://doi.org/10.1080/01596306.2013.822620 
Curtis-Boles, H., Chupina, A. G., \& Okubo, Y. (2020). Social justice challenges: Students of color and critical incidents in the graduate classroom. Training \& Education in Professional Psychology, 14(2), 100-108. https://doi.org/10.1037/tep0000293

Dervin, F. (2015). Interculturality in education: A theoretical and methodological toolbox. London: Palgrave Macmillan.

Geertz, C. (1973). The interpretation of cultures: Selected essays. New York: Basic Books.

Ghafarpour, H. (2017). Classroom conversation analysis and critical reflective practice: Self-evaluation of teacher talk framework in focus. RELC Journal, 48(2), 210-225. https://doi.org/10.1177/0033688216631173

Glenn, P. J. (2003). Laughter in interaction. Cambridge: Cambridge University Press.

Goffman, E. (1981). Forms of talk. Oxford/Philadelphia: Basil Blackwell/University of Pennsylvania Press.

Goffman, E. (1983). The interaction order. American Sociological Review, 48(1), 1-17. https://doi.org/10.2307/2095141

Goodwin, C. (2016). Narrative as talk in interaction. In A. de Fina \& A. Georgakopoulou (Eds.), Handbook of narrative analysis (pp. 196-215). Malden: Wiley-Blackwell.

Halbwachs, M. (2006). On collective memory (6th ed.). Chicago: University of Chicago Press.

Hale, C. C., Nanni, A., \& Hooper, D. (2018). Conversation analysis in language teacher education: An approach for reflection through action research. Hacettepe University Journal of Education, 33, 54-71. doi: 10.16986/HUJE.2018038796

Harper, S. R. (2015). Black male college achievers and resistant responses to racist stereotypes at predominantly white colleges and universities. Harvard Educational Review, 85(4), 646-674. https://doi.org/10.17763/0017$\underline{\text { 8055.85.4.646 }}$

Holliday, A. (2011). Intercultural communication and ideology. London: Sage.

Hormel, U., \& Jording, J. (2016). Kultur/Nation. In P. Mecheril, V. Kourabas, \& M. Rangger (Eds.), Handbuch Migrationspädagogik (pp. 211-225). Weinheim: Beltz.

Hult, F. M. (2019). Toward a unified theory of language development: The transdisciplinary nexus of cognitive and sociocultural perspectives on social activity. The Modern Language Journal, 103, 136-144.

https://doi.org/10.1111/modl.12527

Knoblauch, H. (2005). Die kommunikative Konstruktion kultureller Kontexte. In I. Srubar, J. Renn, \& U. Wenzel (Eds.), Kulturen vergleichen: sozial- und 
kulturwissenschaftliche Grundlagen und Kontroversen (pp. 172-194). Wiesbaden: Verlag für Sozialwissenschaften.

Koreik, U., \& Fornoff, R. (2020). Landeskunde/Kulturstudien und kulturelles

Lernen im Fach DaF/DaZ. Eine Bestandesaufnahme und kritische Positionierung. Zeitschrift für interkulturellen Fremdsprachenunterricht, 25(1), 563-648.

Kramsch, C. (2009a). Cultural perspectives on language learning and teaching. In

H. G. Widdowson, B. Seidlhofer, \& K. Knapp (Eds.), Handbook of foreign language learning and teaching (pp. 219-245). Berlin: Mouton de Gruyter. Kramsch, C. (2009b). Third culture and language education. In L. Wei \& V. Cook

(Eds.), Contemporary applied linguistics I: Language teaching and learning (pp. 234-254). London: Continuum.

Kramsch, C. (2011). The symbolic dimensions of the intercultural. Language

Teaching, 44(3), 354-367.

Kurhila, S. (2006). Second language interaction. Amsterdam: John Benjamins.

Kuure, L., Riekki, M., \& Tumelius, R. (2018). Nexus analysis in the study of the changing field of language learning, language pedagogy and language teacher education. AFinLA-e. Soveltavan Kielitieteen Tutkimuksia, 11, 7192. https://doi.org/10.30660/afinla.69208

Lane, P. (2014). Nexus analysis. In J.-O. Östman \& J. Verschueren (Eds.), Handbook of pragmatics online (pp. 1-18). Amsterdam: John Benjamins.

Lee, J., Jon, J.-E., \& Byun, K. (2016). Neo-racism and neo-nationalism within east Asia: The experiences of international students in south Korea. Journal of Studies in International Education, 21(2), 136-155.

https://doi.org/10.1177/1028315316669903

Linell, P. (1998). Approaching dialogue. Talk, interaction and contexts in dialogical perspectives. Amsterdam: John Benjamins.

Lu, L. (2012). The formation of cultural stereotypes in English language textbooks. In Y. Wang (Ed.), Education and educational technology (pp. 709-713). Berlin: Springer.

Marques-Schäfer, G., Filho, E. S. B., \& Stanke, R. S. (2016). Was können

Lehrwerke zur Reflexion von Stereotypen im DaF-Unterricht beitragen? Eine Analyse anhand der Arbeit mit DaF kompakt in Brasilien. Informationen Deutsch als Fremdsprache, 43(5), 566-586. https://doi.org/10.1515/infodaf-2016-0506

Mori, J. (2003). The construction of interculturality: A study of initial encounters between Japanese and American students. Research on Language and Social Interaction, 36(2), 143-184. https://doi.org/10.1207/S15327973RLSI3602_3

Nash, K. (2001). The 'cultural turn' in social theory: Towards a theory of cultural 
politics. Sociology, 35(1), 77-92.

https://doi.org/10.1177/0038038501035001006

Norton, L. (2019). Action research in teaching and learning: A practical guide to conducting pedagogical research in university. Abingdon: Routledge.

Plikat, J. (2016). Fremdsprachliche Diskursbewusstheit als Zielkonstrukt des Fremdsprachenunterrichts. Bern: Peter Lang.

Powell, R. (2000). Overcoming cultural racism: The promise of multicultural education. Multicultural Perspectives, 2(3), 8-14.

Rellstab, D. H. (2021). Legitime Sprachen, legitime Identitäten.

Interaktionsanalysen im spätmodernen „Deutsch als Fremdsprache“Klassenzimmer. Bielefeld: Transcript.

Riedner, R. (2015). Das Konzept der symbolic competence (Claire Kramsch) im Schnittpunkt von Linguistik, Kulturwissenschaft und Fremdsprachendidaktik. In M. Dobstadt, C. Fandrych, \& R. Riedner (Eds.), Linguistik und Kulturwissenschaft. Zu ihrem Verhältnis aus der Perspektive des Faches Deutsch als Fremd- und Zweitsprache und anderer Disziplinen (pp. 129-150). Frankfurt: Peter Lang.

Roche, J., \& Venohr, E. (2018). Kultur- und Literaturwissenschaften. Tübingen: Narr Francke Attempto.

Sajavaara, K., \& Lehtonen, J. (2011). The silent Finn revisited. In Z. Hua (Ed.), The language and intercultural communication reader (pp. 179-191). London: Routledge.

Schütz, A. (1944). The stranger: An essay in social psychology. American Journal of Sociology, 49(6), 499-507.

Schütz, A. (1953). Common-sense and scientific interpretation of human action. Philosophy and Phenomenological Research, 14(1), 1-38.

Scollon, R., \& Wong Scollon, S. (2004). Nexus analysis. Discourse and the emerging internet. London: Routledge.

Schwingel, M. (2000). Pierre Bourdieu. Zur Einführung. München: Junius.

Selting, M., Auer, P., Barth-Weingarten, D., Bergmann, J., Birkner, K., CouperKuhlen, E., ... \& Uhmann, S. (2009). Gesprächsanalytisches Transkriptionssystem 2 (GAT 2). Gesprächsforschung - Online-Zeitschrift zur verbalen Interaktion, 10. http://www.gespraechsforschungozs.de/heft2009/px-gat2.pdf

Siegel, A. (2016). 'Oh no, it's just culture': Multicultural identities in action in ELF interactions. Journal of Asian Pacific Communication, 26(2), 193-215. https://doi.org/10.1075/japc.26.2.02sie

Skiba, D. (2007). Das Kind im Bade. Komplementäre Kulturbegriffe im Fach 
Deutsch als Fremdsprache. In R. Eßer \& H.-J. Krumm (Eds.), Bausteine für Babylon. Sprache, Kultur, Unterricht. Festschrift zum 60. Geburtstag von Hans Barkowski (pp. 91-102). München: Iudicium.

Wacquant, L. (2016). A concise genealogy and anatomy of habitus. The

Sociological Review 64(1), 64-72. https://doi.org/10.1111/1467$\underline{954 X .12356}$

Walsh, S., \& Mann, S. (2015). Doing reflective practice: A data-led way forward. Reflective practice: Current challenges. ELT Journal, 69, 351-362. https://doi.org/10.1093/elt/ccv018

Wolf, G. (2011). Vergleichende Kultur- und Mentalitätsforschung. In H.-J. Krumm, C. Fandrych, \& B. Hufeisen (Eds.), Deutsch als Fremd- und Zweitsprache. Ein internationales Handbuch (pp. 1431-1441). Berlin: Mouton de Gruyter. Wong Scollon, S., \& de Saint-Georges, I. (2012). Mediated discourse analysis. In J. P. Gee \& M. Handford (Eds.), Handbook of discourse analysis, Vol. 32 (pp. 66-78). Abingdon: Roudledge.

Zimmerman, E. (2007). Constructing Korean and Japanese interculturality in talk: Ethnic membership categorization among users of Japanese. Pragmatics 17(1), 71-94. https://doi.org/10.1075/prag.17.1.02zim 